\title{
MARIALITIC SCAPOLITE OCCURENCES FROM THE KIMMERIA-LEFKOPETRA METAMORPHIC CONTACT, XANTHI (N. GREECE)
}

\author{
Mouchos E. ${ }^{1,2}$, Papadopoulou L. ${ }^{1}$, Williamson B.J. ${ }^{2}$ and Christofides G. ${ }^{1}$ \\ ${ }^{1}$ Aristotle University of Thessaloniki, Department of Geology, 54124, Thessaloniki, Greece, \\ lambrini@geo.auth.gr,christof@geo.auth.gr \\ ${ }^{2}$ Camborne School of Mines, University of Exeter, Penryn, Cornwall, TR10 9FE, UK, \\ em415@exeter.ac.uk,b.j.williamson@exeter.ac.uk
}

\begin{abstract}
Emplacement of the Xanthi Plutonic Complex within the Rhodope Massif of N. Greece created an extensive metamorphic aureole around the plutonite. The aureole contains two areas of intense scapolitization in the contacts between granodiorite and biotitegneiss and between monzonite and sandstone, the latter cross-cut by andesite dykes. This paper reports the results of a mineralogical and geochemical study into the formation of the scapolites and particularly the nature of the plutonite-derived hydrothermal fluids from which scapolites were formed.

Keywords: Xanthi Plutonic Complex, scapolitization, marialite.
\end{abstract}

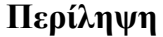

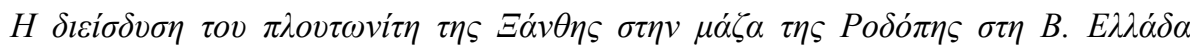

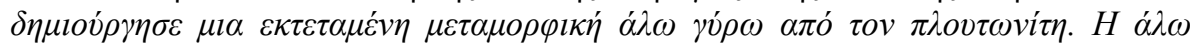

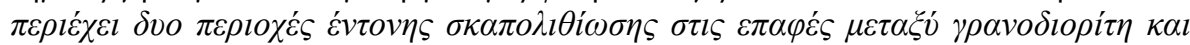

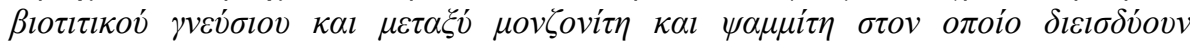

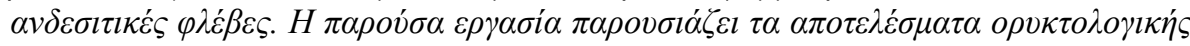

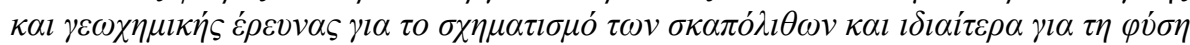

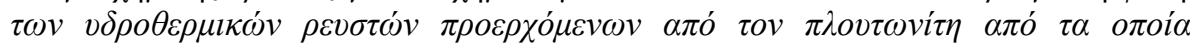

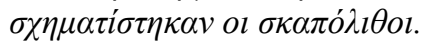

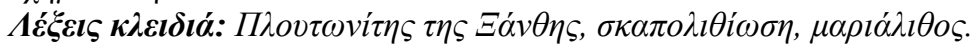

\section{Introduction}

Scapolite-group minerals are tetragonal framework aluminosilicates with a general formula: $M_{4} T_{12} O_{24} A$, where $M=\mathrm{Ca}, \mathrm{Na}, \mathrm{K}$ and $\mathrm{Sr}, T=\mathrm{Si}$ and $\mathrm{Al}$ and $A=\mathrm{Cl}, \mathrm{CO}_{3}$, and $\mathrm{SO}_{4}$ (Deer et al., 2013). Their compositions vary between the end-members marialite $\left(\mathrm{Na}_{4}\left(\mathrm{Al}_{3} \mathrm{Si}_{9} \mathrm{O}_{24}\right) \mathrm{Cl}\right)$ and meionite $\left(\mathrm{Ca}_{4}\left(\mathrm{Al}_{6} \mathrm{Si}_{6} \mathrm{O}_{24}\right) \mathrm{CO}_{3}\right)$ which are not found in nature but can be synthesized (e.g. Eugster and Prostka, 1960; Eugster et al., 1962; Goldsmith and Newton, 1977; Sokolova et al., 1996; Sherriff et al., 2000). In natural systems, the composition of Cl-bearing scapolite ranges between three endmembers: $\mathrm{Na}_{4}\left(\mathrm{Al}_{3} \mathrm{Si}_{9} \mathrm{O}_{24}\right) \mathrm{Cl}, \mathrm{Na}_{3} \mathrm{Ca}\left(\mathrm{Al}_{4} \mathrm{Si}_{8} \mathrm{O}_{24}\right) \mathrm{Cl}$, and $\mathrm{NaCa}_{3}\left(\mathrm{Al}_{5} \mathrm{Si}_{7} \mathrm{O}_{24}\right) \mathrm{CO}_{3}(\mathrm{Pan}, 1998)$. Scapolite has no industrial uses but is a minor gemstone that exhibits chatoyancy, creating a cat's eye effect when cut en cabochon (Bonewitz, 2005). 
Scapolite is found in a wide range of geological settings but most commonly in metamorphic and metasomatic rocks. Its presence has been described in low-pressure skarns, low to medium pressure regional metamorphic rocks, medium to high pressure/depth assemblages of amphibolite and granulite facies and even in kimberlites and basalts (Baker and Newton, 1994 and references therein). It is also thought to occur as a primary mineral in alkaline igneous rocks (Larsen, 1981; Goff et al., 1982). Well-known occurrences of scapolite in Greece include the Serifos Island skarn (Mposkos, 1978), the Kerdillion Unit amphibolites of the Serbo-Macedonian Massif (Rentina and Stratoni areas) (Kassoli-Fournaraki, 1981), the Chalkidiki peninsula quartz amphibolites (Sarti area) (Kassoli-Fournaraki, 1991) and the eastern Rhodope amphibolitized eclogites (Organi-Kimi area) (Mposkos and Mpaziotis, 2005).

Where scapolite occurs proximal to magmatic intrusions, its formation is likely to be due to metasomatic processes (Deer et al., 2013). Scapolitization can occur sequentially or contemporaneously with other metasomatic processes like albitization, as both require saline fluids (Touret and Nijland, 2013). However, why scapolitization occurs instead of other metasomatic processes remains unclear. An obviously important control is the nature of the hydrothermal fluid from which it forms. To investigate this we have carried out a case study in the metamorphic aureole of the Xanthi Plutonic Complex (XPC), Rhodope Massif, Greece, where scapolite is particularly well developed and it has a clear spatial and temporal association with intrusive magmatic rocks (Christofides, 1977). The objective of this study was to carry out mineralogical and geochemical studies on scapolite to investigate the nature of metasomatic fluids responsible for its formation.

\section{Geological Setting}

The evolution of the Rhodope Massif during the Oligocene to Miocene was heavily influenced by the presence of fault-controlled sedimentary basins (Caracciolo et al., 2011; Kilias et al., 2011) and calc-alkaline to high-K calc-alkaline intrusive and extrusive magmatism. Intrusive rocks include those of the XPC which were emplaced into gneisses, mica schists, amphibolites, calc-silicate rocks, marbles and Eocene-Oligocene sedimentary rocks of the Rhodope Massif (Fig. 1). To the south, the XPC has a fault contact with Neogene and Quaternary rocks (Christofides et al., 2010). From geophysical data (Maltezou and Brooks, 1989; Tsokas et al., 1996), the XPC is a laccolith-shaped body that extends several kilometers to the south.

The $40 \mathrm{~km}^{2}$ (10.5 km length and $4.5 \mathrm{~km}$ width) XPC mainly consists of two rock groups: an 'acid' group containing granodiorites grading into monzogranites, with microgranular mafic enclaves of quartz diorite composition; and a 'basic' group composed of monzonite/quartz monzonite, quartz monzodiorite and subordinate monzogabbro and olivine gabbro. The $\mathrm{SiO}_{2}$ content of the XPC ranges from 62-69 wt.\% for the 'acid' group and 44-61 wt.\% for the 'basic' group (Christofides et al., 2010). The age of the XPC has been estimated at 25-29 Ma (Liati, 1986; Bigazzi et al., 1994), however Christofides et al. (2012) recently determined an age of $34.3 \pm 0.5 \mathrm{Ma}$ for the granodiorite rock type.

Christofides et al. (2010), estimated that the XPC initially crystallized under relatively dry conditions at $5.8 \mathrm{kbar}$ pressure and $1300^{\circ} \mathrm{C}$ maximum temperature. This temperature reflects the initial crystallization of the gabbroic magma immediately after emplacement. In a subsequent phase, the water content of the melt increased (to more than $4 \mathrm{wt} . \%$ ) at an average temperature of $870^{\circ} \mathrm{C}$. The increase in melt-water content allowed magma to reach higher crustal levels at lower pressure (average of $1.8 \mathrm{kbar}$ ). The 'acid' group crystallized under oxidizing conditions at $729^{\circ} \mathrm{C}$ average temperature and $0.7 \mathrm{kbar}$ pressure (Christofides et al., 2010). These P/T conditions are significantly lower compared to those of the 'basic' group. This fact potentially suggests a different origin and/or evolution of the 'acid' and 'basic' group. 


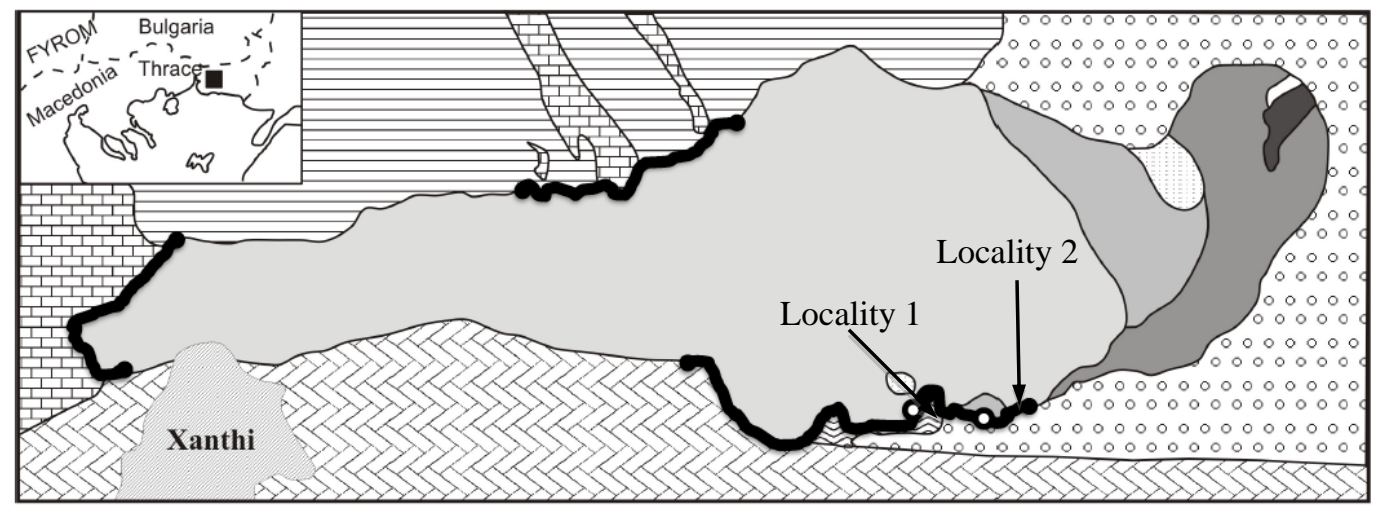

LEGEND

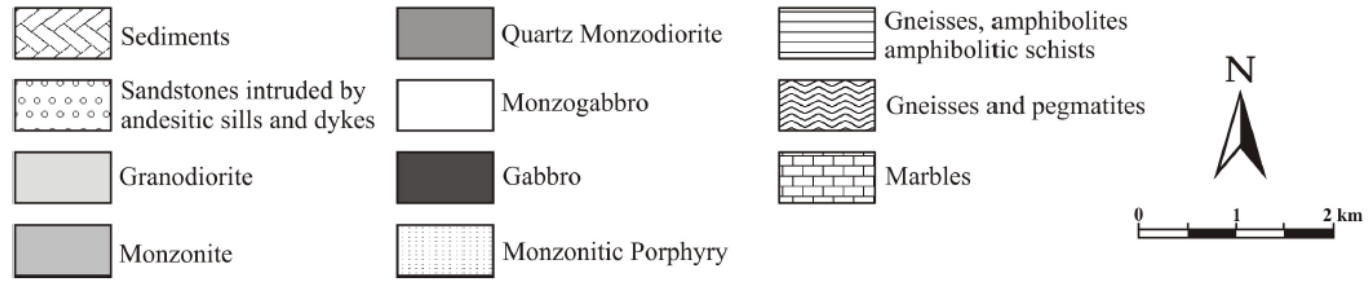

Figure 1 - Geological map of the Xanthi Plutonic Complex (modified after Christofides et al., 2010). The contact metamorphic aureole surrounds the plutonite but is more intense and visible in the bold areas. The two points indicate the positions of the scapolite occurrences. Scapolite at Locality 1 occurs at the contact between granodiorite and biotite-gneiss whereas that at Locality 2 is at the contact between monzonite and sandstones (intruded by andesitic dykes).

The XPC, which is mostly undeformed and unweathered, has an extensive (around 300m thick) contact metamorphic aureole that is mostly visible in contact with marbles and contains a massive Au-bearing skarn-type mineralization, a Mo-Cu-Bi-W vein mineralization and a magnetite ore deposit (Christofides, 1977; Liati, 1986; Vavelidis et al., 1990; Skarpelis and Liati, 1991; Voudouris et al., 2010; Melfos and Voudouris, 2012). Scapolite mostly occurs in the southern part of the complex, best seen north of Lefkopetra village (Fig. 1), at the 'Kimmeria-Lefkopetra' contact, between the granodiorite and biotite-gneiss (Locality 1) and monzonite and sandstones (intruded by andesite dykes) (Locality 2).

\section{Materials and Methods}

Scapolite samples were analyzed using a Philips PW1820/00 X-ray diffractometer equipped with a PW1710/00 microprocessor (CuK $\alpha$ radiation, Ni filter, $35 \mathrm{kV}$ and $25 \mathrm{~mA}$ ) at the Department of Mineralogy-Petrology-Economic Geology, School of Geology, Aristotle University of Thessaloniki (AUTh). Samples were typically scanned at room temperature over angles of $3-63^{\circ} 2 \theta$ with a $1.2^{\circ}$ $2 \theta$ minimum scan velocity. The resulting patterns were interpreted using PC-APD (1994) software by matching peaks with those for minerals in the ICDDPDF database. Imaging in backscattered electron mode (BSE, for average atomic number contrast) and chemical analyses were performed on polished thin sections and resin blocks in a JEOL JSM-840A scanning electron microscope (SEM) with energy dispersive X-ray spectrometer (EDS) at the Interdepartmental Laboratory of Electron Microscopy of AUTh. The analyses were undertaken at an accelerating voltage of $20 \mathrm{kV}$ and a probe current of $0.4 \mathrm{~mA}$. 


\section{Results}

Scapolite showed very different crystal sizes at the two locations in Fig. 1, reaching up to $10 \mathrm{~cm}$ in length at Locality 1 but being microscopic at Locality 2 . In both locations, scapolite in hand specimen ranged from white to grey or colorless. Powdered samples analyzed by XRD had a marialite composition (Fig. 2). Rock samples from Locality 1 were composed of actinoliteclinopyroxene-scapolite-white mica, whilst those from Locality 2 were consisted of plagioclasescapolite-clinopyroxene-titanite (Fig. 3). Scapolite from both localities is colorless in PPL, with low relief and poor $\{100\}$ to indistinct $\{110\}$ cleavage. Crystals from Locality 1 are often poikilitic containing inclusions of clinopyroxene. Those from Locality 2 surround and often partially replace primary plagioclase (by scapolitization). Where still present, the plagioclase is cloudy in appearance, which, from SEM-EDS analysis, is due to the presence of fine-grained (from less than $100 \mu \mathrm{m}$ to a few $\mathrm{mm}$ ) alteration phases including scapolite, calcite, white mica and orthoclase (Fig. 4). From semi-quantitative SEM-EDS analysis of scapolite from Locality 1 and 2, it can be classified as marialite, containing approximately 11.5 and $8 \mathrm{wt} . \% \mathrm{NaCl}$, respectively.
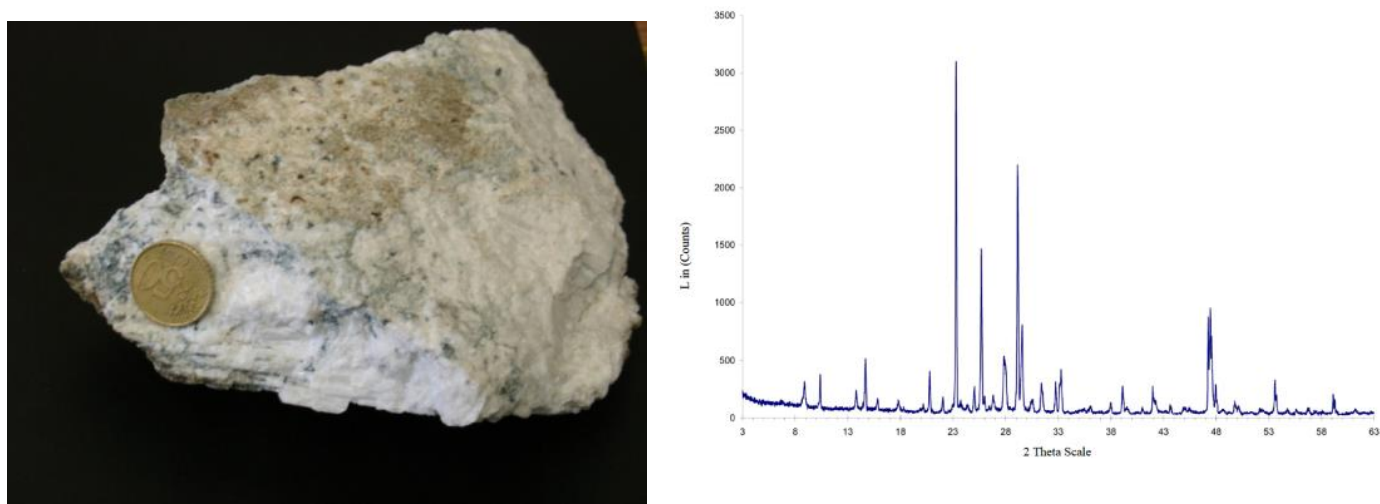

Figure 2 - Photograph of scapolite from Locality 1 (left) and its XRD pattern (right).
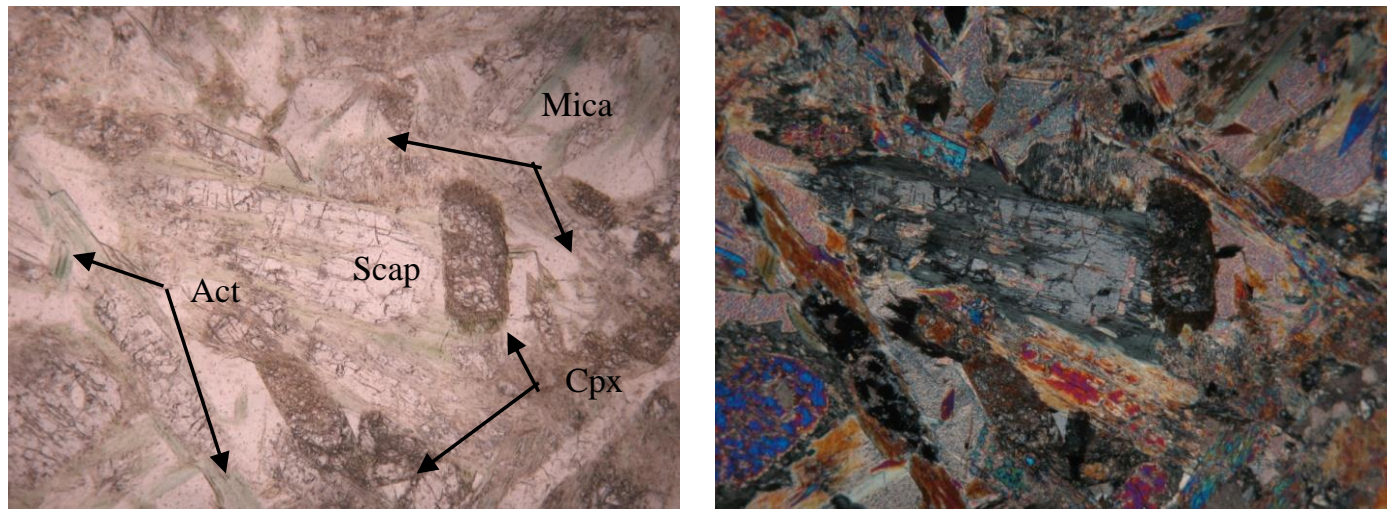

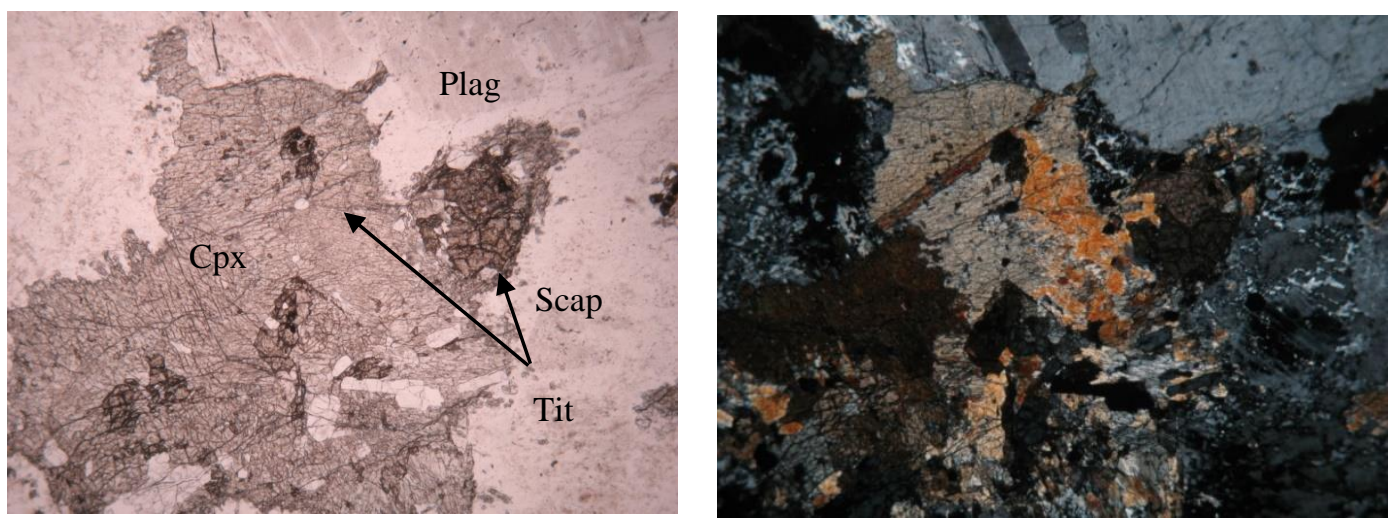

Figure 3 - Photomicrographs (40x) of scapolite from Locality 1 (upper) and 2 (lower) in plane- (PPL, left) and crossed-polarized light (XPL, right). Act = actinolite, $\mathbf{C p x}=$ clinopyroxene, Mica $=$ white mica, Plag $=$ plagioclase, Scap $=$ scapolite, and Tit $=$ titanite .
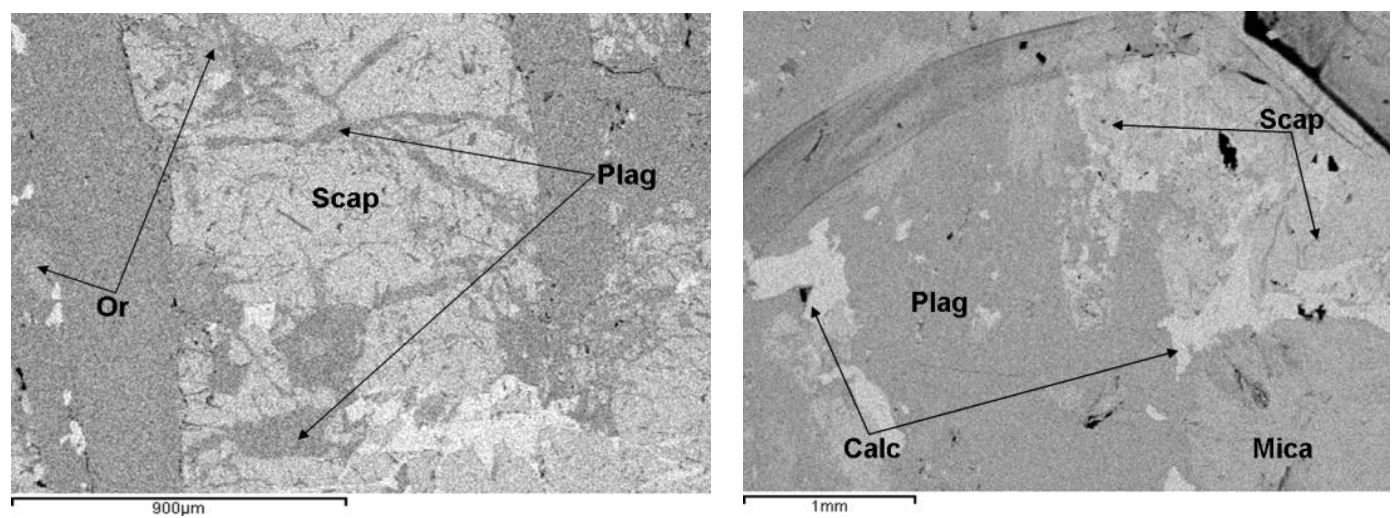

Figure 4 - BSE-SEM images of scapolite from Locality 2. Scap = scapolite, Plag = plagioclase, Calc $=$ calcite, Mica $=$ white mica and Or $=$ orthoclase.

\section{Discussion}

Scapolite within skarns almost invariably shares its host's metasomatic origin, formed due to the action of metasomatic fluids expelled during the emplacement and crystallization of proximal magmatic intrusions (Einaudi et al., 1981). In most circumstances, scapolite forms by replacement of plagioclase due to the process of scapolitization. Such replacement is thought to be driven by interaction of plagioclase with fluids containing $\mathrm{Cl}^{-}, \mathrm{CO}_{2}, \mathrm{SO}_{3}$ and $\mathrm{Na}^{+}$, rather than by isochemical transformation (Kullerud and Erambert, 1999). When the fluids contain high concentrations of $\mathrm{SO}_{2}$ and $\mathrm{CO}_{2}$, the formation and stabilization of meionite (Ca-rich scapolite) is favoured. On the contrary, a Cl-rich fluid phase favours the formation and stabilization of marialite (Na-rich scapolite). The composition of scapolite is largely controlled by the following linked substitutions: $\mathrm{Na}^{+} \leftrightarrow \mathrm{Ca}^{2+}$, $\mathrm{Al}^{3+} \leftrightarrow \mathrm{Si}^{4+}$ and $\mathrm{Cl}^{-} \leftrightarrow \mathrm{CO}_{3}^{-2}$. All three substitutions are active in Na-rich scapolite $[\mathrm{Ca} /(\mathrm{Ca}+\mathrm{Na})<0.75]$, whereas $\mathrm{Cl}$ is completely replaced by $\mathrm{CO}_{3}$ in Ca-rich scapolite $[\mathrm{Ca} /(\mathrm{Ca}+\mathrm{Na})>0.75]$ and hence the chemical reaction is controlled only by the $\mathrm{NaSi} \leftrightarrow \mathrm{CaAl}$ double substitution (Strauss, 2003).

Scapolite can be a potential indicator for the activity of volatiles during various processes that take place in the Earth's crust. This is because of its ability to incorporate volatile elements and compounds such as $\mathrm{Cl}, \mathrm{CO}_{2}$ and $\mathrm{SO}_{3}$, and due to the fact that scapolite can equilibrate in a wide range of pressure and temperature environments. There are many papers in the literature that contain 
quantitative calculations on the volatile activity of metamorphic fluids based on the chemistry of scapolite (e.g. Ellis, 1978; Moecher and Essene, 1991; Harley et al., 1994; Gómez-Pugnaire et al., 1994). Nowadays, there are two diametrically opposed views on the distribution of volatile components between scapolite and fluids. The first one suggests that the $\mathrm{Cl}$ content of scapolite is heavily dependent on the limitations imposed by the cationic lattice in the balance of valences (Pan et al., 1994). The second one claims that $\mathrm{Cl}$ content of scapolite is mainly controlled by the activity of $\mathrm{NaCl}$ in fluids that are in equilibrium with the mineral (Jiang et al., 1994).

In addition to this, $\mathrm{F}$ and $\mathrm{Cl}$ are ubiquitous (in various amounts from ppm to wt.\%) in fluids at all crustal levels (Markl and Piazolo, 1998). These two elements occur in many metamorphic rockforming minerals and consequently can be determined in order to estimate their ratios in metamorphic fluids (Munoz and Swenson, 1981; Zhu and Sverjensky, 1991; Harley and Buick, 1992; Markl and Bucher, 1998). As a result, the chemistry of scapolite, and particularly its $\mathrm{Cl}$ and $\mathrm{CO}_{2}$ contents, in relation to the $\mathrm{Cl}$ and $\mathrm{F}$ content of other coexisting common metamorphic rockforming minerals, such as amphibole, mica, apatite and titanite, can be used as tracers for the chemical composition of the metamorphic fluid (Ellis, 1978; Munoz and Swenson, 1981; Binder and Troll, 1989; Mora and Valley, 1989; Kullerud, 1996; Rebbert and Rice, 1997; Markl and Bucher, 1998; Kullerud and Erambert, 1999; Yardley et al., 2000; Svensen et al., 2001).

The formation of marialite requires saline (around $20 \mathrm{wt} \% \mathrm{NaCl}$ ) metasomatic fluids (Vanko and Bishop, 1982), which means that Cl-rich scapolite is an indicator of high $\mathrm{NaCl}$ activity during crystallization (Orville, 1975; Ellis, 1978; Vanko and Bishop, 1982). NaCl may have been original to the system or may have been derived from an external source (such as nearby sedimentary rocks, halite-bearing rocks or brines) through fluid migration. Fluid inclusion studies indicate that the salinity of metamorphic fluids ranges from 0-6 wt.\% in pelitic schists and gneisses, 20-25 wt.\% in calcareous rocks and up to $50 \mathrm{wt} . \% \mathrm{NaCl}$ equivalent in evaporates (Mora and Valley, 1989, and references therein). However, when scapolite contains low levels of $\mathrm{NaCl}(<20 \mathrm{wt} . \%)$, as in those from both localities, it is unclear if it is formed from low salinity magmatic fluids, ingress of saline meteoric waters or a mixture of both, which can cause a decrease in fluid temperature and salinity.

Finally, $\mathrm{NaCl}$-rich scapolite was synthesized at temperatures higher than $700-800^{\circ} \mathrm{C}$ and at low to high pressure (Eugster and Prostka, 1960; Newton and Goldsmith, 1975). This temperature range is not significantly different from the crystallization temperature of granodiorite and monzonite. Hence, it can be considered that scapolite from Locality 1 formed at $729^{\circ} \mathrm{C}$ and $0.7 \mathrm{kbar}$, and in equilibrium with the fluid phase, as it seems that the plutonic plagioclase was completely replaced by scapolite. Incomplete scapolitization at Locality 2 took place at $870^{\circ} \mathrm{C}$ and approximately 1.8 kbar pressure. Scapolitization at both localities occurred under the influence of magmatic fluids emanating from crystallizing magma that formed the XPC, particularly after the initial stage of cooling when melt-water contents increased allowing the magma to reach shallower emplacement levels.

\section{Conclusions}

Scapolite in the case study was formed and developed by replacement of igneous plagioclase through metasomatic reactions within the contact aureole of the XPC. Complete scapolitization at Locality 1 took place at $729^{\circ} \mathrm{C}$ and $0.7 \mathrm{kbar}$ by interaction of the cooling granodiorite with fluids containing 11.5 wt. $\% \mathrm{NaCl}$. On the other hand, incomplete scapolitization at Locality 2 occurred at slightly higher temperatures and pressures $\left(870^{\circ} \mathrm{C}\right.$ and $\left.1.8 \mathrm{kbar}\right)$ and during interaction with lower salinity $(8 \mathrm{wt} . \% \mathrm{NaCl})$ fluids during the cooling of monzonite. Differences in the chemistry of scapolite from Locality 1 and 2, with varying substitution of $\mathrm{Na}^{+} \leftrightarrow \mathrm{Ca}^{2+}, \mathrm{Al}^{3+} \leftrightarrow \mathrm{Si}^{4+}$ and $\mathrm{Cl}^{-} \leftrightarrow \mathrm{CO}_{3}^{-2}$, are likely to reflect slight differences in the salinity of the metasomatic fluids from which they were formed. However, the cause of the variations in the temperature and salinity of the metasomatic fluids remains to be determined. Further to this, the reasons for the abrupt end to the scapolitization process 
at Locality 2, as well as the role of the nearby sediments and andesitic intrusions as a potential source for $\mathrm{NaCl}$-rich fluids, requires further research.

\section{References}

Baker, J. and Newton, R.C., 1994. Standard thermodynamic properties of meionite, $\mathrm{Ca}_{4} \mathrm{Al}_{6} \mathrm{Si}_{6} \mathrm{O}_{24} \mathrm{CO}_{3}$, from experimental phase equilibrium data, American Mineralogist, 79, 478-484.

Bigazzi, N.S.G., Christofides, G., Del Moro, A. and Kyriakopoulos, K., 1994. A contribution to the evolution of the Xanthi pluton (Northern Greece): The apatite fission track analysis, Bull. Soc. Geol. It., 113, 243-248.

Binder, G. and Troll, G., 1989. Coupled anion substitution in natural carbon-bearing apatites, Contrib. Mineral. Petrol., 101, 394-401.

Bonewitz, R.L., 2005. Smithsonian Rock and Gem: The definitive guide to rocks, minerals, gems, and fossils, D.K. Publishing Inc./Smithsonian Institution and Dorling Kindersley Limited, 254 pp.

Caracciolo, L., Critelli, S., Innocenti, F., Kolios, N. and Manetti, P., 2011. Unraveling Provenance From Eocene-Oligocene Sandstones Of The Thrace Basin, North-East Greece, Sedimentology, 58, 1988-2011.

Christofides, G., 1977. Contribution to the study of plutonic rocks in the area of Xanthi, PhD thesis, Aristotle University of Thessaloniki, 249 pp. (In Greek).

Christofides, G., Papadopoulou, L., Soldatos, T., and Koroneos, A., 2010. Crystallization conditions of the Xanthi Plutonic Complex (Rhodope Massif, N. Greece): geothermometry and geobarometry, Scientific Annals, School of Geology, Aristotle University of Thessaloniki, Proceedings of the XIX CBGA Congress, Thessaloniki, Greece, Special volume 99, 199-207.

Christofides, G., Pipera, K., Koroneos, A. and Papadopoulos, A., 2012. New geochronological data from the Xanthi pluton: Constraints on the Nestos thrust dating, The School of Prof. Zhivko Ivanov, International Conference: Exhumation of High-grade Metamorphic Rocks (MCC), Magmatic Arc Systems and Strrike-slip Zones, 49-52.

Deer, W.A., Howie, R.A. and Zussman, J., 2013. An introduction to the rock-forming minerals, $3^{\text {rd }}$ ed., The Mineralogical Society, London. 498 pp.

Einaudi, M.T., Meinert, L.D. and Newberry, R.J., 1981. Skarn deposits, Econ. Geology, 75 ${ }^{\text {th }}$ Anniversary Volume, 317-391.

Ellis, D.E., 1978. Stability and phase equilibria of chloride and carbonate bearing scapolites at $750^{\circ} \mathrm{C}$ and 4000 bar, Geochimica et Cosmochimica Acta, 42, 1271-1281.

Eugster, H. and Prostka, H.J., 1960. Synthetic scapolites, Geological Society of America Bulletin, $71,1858$.

Eugster, H., Prostka, H.J. and Appleman, D.E., 1962. Unit cell dimensions of natural and synthetic scapolites, Science, 137, 853-854.

Goff, F., Arney, B.H. and Eddy, A.C., 1982. Scapolite phenocrysts in a latite dome, northwest Arizona, U.S A, Earth and Planetary Science Letters, 60, 86-92.

Goldsmith, J.R. and Newton, R.C., 1977. Scapolite-plagioclase stability relations at high pressures and temperatures in the system $\mathrm{NaAlSi}_{3} \mathrm{O}_{8}-\mathrm{CaAl}_{2} \mathrm{Si}_{2} \mathrm{O}_{8}-\mathrm{CaCO}_{3}-\mathrm{CaSO}_{4}$, Am. Mineral, 62, 1063-1081.

Gómez-Pugnaire, M.T., Franz, G. and Sanchez-Vizcaino, V.L., 1994. Retrograde formation of $\mathrm{NaCl}$-scapolite in high pressure metaevaporites from the Cordilleras Beticas (Spain), Contrib. Mineral. Petrol., 116, 448-461.

Harley, S.L. and Buick, I.S., 1992. Wollastonite-scapolite assemblages as indicators of granulite pressure-temperature-fluid histories: the Rauer Group, East Antarctica, Journal of Petrology, 33, 693-728.

Harley, S.L., Fitzsimons, I.C.W. and Buick, I.S., 1994. Reactions and textures in wollastonitescapolite granulites and their significance for pressure-temperature-fluid histories of highgrade terranes, Precambrian Research, 66, 309-323.

Jiang, S.-Y., Palmer, M.R., Xue, C.-J. and Li, Y.-H., 1994. Halogen-rich scapolite-biotite rocks from the Tongmugou $\mathrm{Pb}-\mathrm{Zn}$ deposit, Qinling, north-western China: Implications for the oreforming processes, Mineral. Mag., 58, 543-552. 
Kassoli-Fournaraki, A., 1981. Contribution to the mineralogical and petrological study of amphibolitic rocks of the Serbomacedonian massif. $\mathrm{PhD}$ thesis, Aristotle University of Thessaloniki, 231 pp. (In Greek).

Kassoli-Fournaraki, A., 1991. Ca-rich scapolite in quartz amphibolites from the Sarti area, northern Greece, Eur. J. Min., 3, 887-94.

Kilias, A., Falalakis, G., Sfeikos, A., Papadimitriou, E., Vamvaka, A. and Gkarlaouni, Ch., 2011. Architecture of Kinematics and Deformation History of the Tertiary Supradetachment Thrace Basin: Rhodope Province (NE Greece), In: New Frontiers in Tectonic Research - At the Midst of Plate Convergence, In Tech, 241-268.

Kullerud, K., 1996. Chlorine-rich amphiboles: Interplay between amphibole composition and an evolving fluid, European Journal of Mineralogy, 8, 355-370.

Kullerud, K. and Erambert, M., 1999. Cl-scapolite, Cl-amphibole, and plagioclase equilibria in ductile shear zones at Nusfjord, Lofoten, Norway: Implications for fluid compositional evolution during fluid-mineral interaction in the deep crust, Geochimica et Cosmochimica Acta, 63, 3829-3844.

Larsen, J.G., 1981. Medium pressure crystallization of a monchiquitic magma: Evidence from megacrysts of Drever's block, Ubekendt Ejland, West Greenland, Lithos, 14, 241-262.

Liati, A., 1986. Regional metamorphism and overprinting contact metamorphism of the Rhodope Zone, near Xanthi (N. Greece): petrology, geochemistry, geochronology, PhD thesis, Techn. Univ. Braunschweig, $186 \mathrm{pp}$.

Maltezou, F. and Brooks, M., 1989. A geophysical investigation of post-Alpine granites and Tertiary sedimentary basins in northern Greece, Journal of the Geologial Society, London, 146, 53-59.

Markl, G. and Bucher, K., 1998. Composition of fluids in the lower crust inferred from metamorphic salt in lower crustal rocks, Nature, 391, 781-783.

Markl, G. and Piazolo, S., 1998. Halogen-bearing minerals in syenites and high-grade marbles of Dronning Maud Land, Antarctica: monitors of fluid compositional changes during late-magmatic fluid-rock interaction processes, Contributions to Mineralogy and Petrology, 132, 246-268.

Melfos, V. and Voudouris, P.C., 2012. Geological, Mineralogical and Geochemical Aspects for Critical and Rare Metals in Greece, Minerals, 2, 300-317.

Moecher, D.P. and Essene, E.J., 1991. Calculation of $\mathrm{CO}_{2}$ activities using scapolite equilibria: Constraints on the presence and composition of a fluid phase during high grade metamorphism, Contrib. Mineral. Petrol., 108, 219-240.

Mora, C.I. and Valley, J.W., 1989. Halogen-rich scapolite and biotite: Implications for metamorphic fluid-rock interactions, Am. Mineral., 74, 721-737.

Mposkos, E. and Baziotis, I., 2005. Petrology and geochemistry of amphibolitized eclogites and trondhjemitic dykes from Organi-Kimi area of Eastern Rhodope, $2^{\text {nd }}$ conference of the Committee of Economic Geology, Mineralogy and Geochemistry of the Geological Society of Greece, 259-268 (In Greek).

Mposkos, E., 1978. Scapolite of Seriphos and the garnet composition of several garnetites of the island, Bull. Soc. Geol. Greece, 13(2), 34-45 (In Greek).

Munoz, J.L. and Swenson, A., 1981. Chloride-hydroxyl exchange in biotite and estimation of relative $\mathrm{HCl} / \mathrm{HF}$ activities in hydrothermal fluids, Econ. Geol., 76, 2212-21.

Newton, R.C. and Goldsmith, J.R., 1975. Stability of the scapolite meionite $\left(3 \mathrm{CaAl}_{2} \mathrm{Si}_{2} \mathrm{O}_{8} \mathrm{CaCO}_{3}\right)$ at high pressure and storage of $\mathrm{CO}_{2}$ in the deep crust, Contributions to Mineralogy and Petrology, 49, 49-62.

Orville, P.M., 1975. Stability of scapolite in the system Ab-An-NaCl-CaCO 3 at $4 \mathrm{~kb}$ and $750^{\circ} \mathrm{C}$, Geochimica et Cosmochimica Acta, 39, 1091-1095.

Pan, Y., Fleet, M.E. and Ray, G.E., 1994. Scapolite in two gold deposits: Nickel Plate, British Columbia and Hemlo, Ontario, Canadian Mineral, 32, 825-837.

Pan, Y., 1998. Scapolite in skarn deposits: Petrogenetic and geochemical ignificance. In: Mineralized Intrusion-Related Skarn Systems, Lentz, D.R., ed., Mineralogical Association of Canada Short Course Series, 26, 69-109. 
Rebbert, C.R. and Rice, J.M., 1997. Scapolite-plagioclase exchange: $\mathrm{Cl}-\mathrm{CO}_{3}$ scapolite solution chemistry and implications for peristerite plagioclase, Geochim. Cosmochim. Acta, 61, 555-567.

Sherriff, B.L., Sokolova, E.V., Kabalov, Y.K., Jenkins, D.M., Kunath-Fandrei, G., Goetz, S., Jäger, C. and Schneider, J., 2000. Meionite: Rietveld structure-refinement, ${ }^{29} \mathrm{Si}$ Mas and ${ }^{27} \mathrm{Al}$ Satras NMR spectroscopy, and comments on the marialite-meionite series, Can. Mineral, 38, 1201-1213.

Skarpelis, N. and Liati, A., 1991. Wollastonite and associated copper mineralization in the contact metamorphic aurole of Kimmeria, Xanthi, N. Greece, Bulletin of the Geological Society of Greece, 25(2), 369-377.

Sokolova, E.V., Kabalov, Y.K., Sherriff, B.L., Teertstra, D.K., Jenkins, D.M., Kunath-Fandrei, G., Goetz, S. and Jäger, C., 1996. Marialite: Rietveld structure-refinement and ${ }^{29} \mathrm{Si}$ Mas and ${ }^{27} \mathrm{Al}$ satellite transition NMR spectroscopy, Can. Mineral., 34, 1039-1050.

Strauss, T.A.L., 2003. The geology of the Proterozoic Haveri Au-Cu deposit, Southern Finland, PhD thesis, Rhodes University.

Svensen, H., Jamtveit, B., Banks, D.A. and Austrheim, H., 2001. Halogen contents of eclogite facies fluid inclusions and minerals: Caledonides, western Norway, Journal of Metamorphic Geology, 19, 165-178.

Tsokas, G.N., Christofides, G.C. and Papakonstantinou, C., 1996. A geophysical study of the granites and the sedimentary basins of the Xanthi area (N. Greece), "PAGEOPH", 146, 2, 365-392.

Touret, J.L.R. and Nijland, T.G., 2013. Prograde, peak and retrograde metamorphic fluids and associated metasomatism in upper amphibolite to granulite facies transition zones. In: Harlow, D. and Austrheim, H., eds., Metasomatism and the Chemical Transformation of Rocks, Lecture Notes in Earth System Science. Springer, Berlin-Heidelberg, 415-471.

Vavelidis, M., Michailidis, K., Christofides, G. and Boboti, I., 1990. Geochemical study of placer gold and the gold bearing skarn type mineralization of the Kimmeria area, Xanthi district, NE Greece, Geologica Rhodopica, 2, 297-308.

Vanko, D.A. and Bishop, F.C., 1982. Occurrence and origin of marialitic scapolite in the Humbold lopolith, N.W. Nevada, Contributions to Mineralogy and Petrology, 81, 277-289.

Voudouris, P., Melfos, V., Moritz, R., Spry, P.G., Ortelli, M. and Kartal, T., 2010. Molybdenite Occurrences in Greece: Mineralogy, Geochemistry and Rhenium Content, In: Scientific Annals of the School of Geology AUTH, Proceedings of the XIX Congress of the Carpathian-Balkan Geological Association, Thessaloniki, Greece, 23-26 September 2010, 369-378.

Yardley, B., Gleeson, S., Bruce, S. and Banks, D., 2000. Origin of retrograde fluids in metamorphic rocks, J. Geochem. Explor., 69, 281-285.

Zhu, C. and Sverjensky, D.A., 1991. Partitioning of F-Cl-OH between minerals and hydrothermal fluids, Geochimica et Cosmochimica Acta, 55, 1837-1858. 